\title{
Tax Revenue Productivity of Tax Reforms in Kenya
}

\author{
James Murunga $^{1}$, Nelson W. Wawire ${ }^{2} \&$ Moses K. Muriithi $^{3}$ \\ ${ }^{1}$ PhD Student, Department of Economics, Population and Development Studies, University of Nairobi, Nairobi, \\ Kenya \\ ${ }^{2}$ Professor of Economics, School of Economics, Kenyatta University, Nairobi, Kenya \\ ${ }^{3}$ Senior Lecturer, Department of Economics, Population and Development Studies, University of Nairobi, \\ Nairobi, Kenya \\ Correspondence: James Murunga, PhD Student, Department of Economics, Population and Development Studies, \\ University of Nairobi, Nairobi, Kenya. P.O BOX 30197-00100, Nairobi, Kenya.
}

Received: September 26, 2021

Accepted: October 22, 2021

Online Published: October 30, 2021

doi:10.5539/ijef.v13n12p42

URL: https://doi.org/10.5539/ijef.v13n12p42

\begin{abstract}
Kenya has continued to experience increasing budget deficits. This is despite implementing various tax reforms. To finance the deficit, the Kenyan government should either raise more tax revenue or resort to borrowing. Domestic borrowing crowds out investment while external debt specifically non-concessional loans are tied to some unpopular conditions. The government has an option of considering non-concessional loans but this comes with a price of high interest rates and short payment periods. This means raising more tax with minimum burden is the best option. This study therefore seeks to investigate the responsiveness of Kenya's tax system to GDP and Discretionary tax measures for the period between 1970 and 2018. Variables used in the study are integrated of order one. Johansen cointegration test reveals presence long run relationship thus informing the study to consider Vector Error Correction Model (VECM). The results reveal that Kenya's tax system is inelastic but buoyant. This implies that the Kenyan tax system is unresponsive to GDP but responsive to discretionary tax measures. The finding of inelastic tax system has implications for the fiscal policy. The fiscal policy's managers should target reducing or eliminating the tax exemptions, which might be eroding the effective tax base.
\end{abstract}

Keywords: Kenya, tax buoyancy, tax elasticity, vector error correction model

\section{Introduction}

Tax reform is any attempt to alter the status quo of the tax system. This has been one of the key concerns of most of the developing countries over the years. Most developing countries had to take tax reform as a necessity as opposed to preferred task as a result of the oil shocks of the early 1970s that led to dwindling tax revenue. This led to budget deficits among many developing countries. The budget deficit has remained core subject of most of these countries since 1970s. The cause of the large increase in fiscal imbalance is the expansion in expenditure and low tax revenue collection (Ahmed \& Muhammad, 2010). It is argued that some of the reasons why developing countries experience ballooning budget deficit is because they have small and few sources of tax revenue that are susceptible to shocks. These sources include import and export taxes on agricultural and mineral products whose prices are determined internationally and therefore tend to be unstable. In addition, some countries had sales tax that was narrow based (Wawire, 2017).

The above challenges made developing countries to embark on tax reform starting in 1970s to present. These reforms have targeted tax structure aimed at generating adequate tax. Tax structure has also been targeted to provide efficient, simple, equitable and fair tax system. In addition, there has been tax reforms aimed at strengthening tax administration (Osoro, 1993).

This paper estimates the tax buoyancy and tax elasticity of Kenya's tax system using VECM. This procedure was chosen since the stationarity results revealed that all variables used in the study were integrated of order one, I(1). To the best of our knowledge, this is the first time a study separates informal sector GDP from the recorded GDP while estimating tax productivity.

The next section presents the tax reforms implemented in Kenya, Kenya's economic performance since 1970s and the statement of the problem. Section 2 deals with some of the studies that were conducted on the topic and gives a review of their results. The methodology used to achieve the study's objective is discussed in section 3 . 
In section 4, tax buoyancy and tax elasticity are estimated using the Proportional Adjustment Method (PAM). The paper concludes with some remarks and policy implications.

\subsection{Tax Reforms in Kenya}

From 1963 when Kenya became a self-governed state, taxes and fees inherited from the colonialists became the primary government's source of income (Eissa \& Jack, 2009). Foreign direct inflows were used to supplement taxes and fees collected by the government. The oil shock of the 1970s resulted in the country's first major fiscal crisis. This crisis led to the adoption of reforms in the tax system. The government introduced sales tax to generate more revenue (Eissa \& Jack, 2009). Trade tax was also introduced to counter the increasing trade imbalance caused by high oil prices. The country also introduced trade tax in pursuit of import substitution strategy in the first place and later export-led growth strategies. During this time, personal and corporate income taxes were primarily used to serve a distributive role (Moyi \& Ronge, 2006; Karingi \& Wanjala, 2005). Corporate and Personal income tax rates were very high between 1970 and 1984. During this time, the lowest marginal personal income tax rate was 10 percent, while the highest was 65 percent. The corporation income tax for domestic firms and foreign corporations was 45 percent and 52 percent, respectively. However, the reforms in the income tax did not achieve the intended objective as not much personal income tax was obtained from the upper range of the tax schedule. The failure to collect adequate tax in this bracket of tax schedule resulted from failure to report taxes by the taxpayers in this income bracket (Eissa \& Jack, 2009).

In the 1980s, Kenya's budget deficit increased, leading to the adoption of the Tax Modernization Programme (TMP). This tax reform aimed at increasing tax collection to 22 percent of GDP but later changed to 28 percent in 1992 (Eissa \& Jack, 2009). Kenya also replaced sales tax which was seen to be narrow-based by a broad-based VAT in 1990. This tax was imposed on the consumption of domestic and the imported commodities. The country also implemented income tax reforms. This was in form of income tax rationalization. The income tax brackets were reduced, and the marginal tax rate was reduced from 65 percent to 30 percent (Mutua, 2012). To strengthen the administration of the tax system, Kenya implemented an organizational change in tax management by incorporating Kenya Revenue Authority (KRA) in 1995. Incorporation of KRA was aimed at centralizing tax collection, which was initially carried out by various sections within the Ministry of Finance (Eissa \& Jack, 2009).

From 1995, KRA has undertaken in-house reforms to reduce fraud among its staff and grow taxpayer confidence (Omondi, Wawire, Manyasa, \& Thuku, 2014). Adoption of the Tax Modernization Programme (TMP) and incorporation of KRA led to a gradual increase in tax revenue to GDP from about 15.6 percent of country's GDP to about 25 percent of country's GDP in 1995/96. The tax ratio stabilized at 23 percent in 2000. Since then, the tax ratio has been fluctuating (Omondi et al., 2014). To improve efficiency in the tax system, KRA introduced a computer-generated Personal Identification Number (PIN) in 1997. The PIN is given to any Kenyan above 18 years and who wants to transact with KRA. A PIN holder chargeable to a tax must complete and submit an annual self-assessment return (Mutua, 2012).

Faced with decreased revenue mobilization due to manual processes, KRA recommended a strategy called Revenue Administration Reforms Modernization Programmes (RARMP) implemented in 2004/2005 (Kondo, 2015). Implementation of RARMP described the third stage of tax reforms in the country. The primary goal of this reform was to make the KRA a fully integrated modern and customer-focused body. The Simba system was implemented in 2005. KRA established the Document Processing Centre (DPC) another reform under the RARMP (Atambo \& Katuse, 2017). This action resulted in automating about 90 percent of customs operations. The third reform under this programme was Customs Oil Stocks Information Systems (COSIS) that was implemented. The COSIS is an information and communication technology (ICT) system which monitors and brings together oil stocks of each oil seller. The fourth reform under RARMP occurred in 2005 when the electronic tax register (ETR) was introduced. ETR aimed to mitigate losses in VAT taxes due to poor record-keeping by the business people. The fifth reform under the programme was introduction of integrated tax management system (ITMS) in 2008. The goal of this reform was to ease online registration and filing of returns by taxpayers (Omondi, 2014). These reforms on the Kenyan tax system, in general, led to an increase in tax revenue from KES 17, 093.8 million in 1986 to KES 1,338,284.06 million in 2016 (Republic of Kenya, 2017).

\subsection{Kenya's Economic Performance Since 1970}

The 1970s were tough years in the country's history. This period was characterized by a general worsening of the country's economic performance. There was intervention by the government through the implementation of the import substitution strategy. The government promoted and financed new industrial projects. Production in the manufacturing sector for the export market declined since the policy favoured production for the domestic 
market. This resulted in an inward-looking industrial sector, which was limited by size of local market. Also, the declining economic performance was made worse by the erosion of the country's fiscal discipline occasioned by the second oil crisis of 1977. Under these conditions, the country's products could not do well in export markets. Many industries found it of great importance to supply to protected domestic market to make a profit. This led to an anti-export bias (Newman, Page, Rand, Shimeles, Söderbom, \& Tarp, 2016). Generally, the import substitution posed a threat to some sectors in the economy. For example, the country's agricultural sector greatly suffered high input costs (Kinyanjui, 2013). The reduced export market, dwindling agricultural sector, worsening fiscal climate due to the coffee boom and second oil crisis may have had an inverse impact on tax revenue mobilization in Kenya during the 1970s.

In the 1980s and 1990s, the Kenyan government embraced structural adjustment programmes (SAPs). Bretton Woods institutions proposed strengthening competitiveness by becoming a market-oriented economy. A sessional paper on Economic Management for Renewed Growth (EMRG) resulted in policy and institutional changes during this time. These policy changes were aimed at abolishing anti-export bias. The government also embarked on removing restrictive import licensing and tariffs. In 1994, the country joined other countries to be a member of the world trade organization (WTO), where Kenya became fully opened to international trade. However, even though the SAPs liberalized the domestic economy, exposing it to global competition, the industrial sector remained inward-oriented, majorly import-dependent, excessively capital intensive and incapable of employing the rapidly rising labour force. Other policies meant to increase exports that were adopted included establishing the export promotion council in 1993, establishing export compensation scheme, adopting manufacturing under bond and establishing export processing zones. Other export-oriented strategies included the import duty remission scheme intended to ensure producers who produce for export market access imported inputs at world prices (Bigsten, Kimuyu, \& Söderbom, 2010).

During this period, Kenya's poor economic performance was aggravated by the 1982 attempted coup and a severe drought in 1983 and 1984. There was another biting drought in 1991 and 1992, succeeded by damaging El-Nino rains in 1997 and 1998 and later a drought in 2000 that resulted in power rationing. Also, the country had to grapple with the shocks of the sharp increases in oil prices due to 1991 Persian Gulf War, the aid freeze of 1991 to 1993 and later 1997 to 2000 (Wawire, 2006). These challenges saw the country's inflation reach an extraordinarily high of 46 percent in 1993. The country's average interest rate was 30 percent during the same year, the highest in the country's history (Republic of Kenya, 1997). Further, Kenya suffered economic shocks caused by the tribal clashes that coincided with the 1992 and 1997 General Elections (Wawire, 2006). The inability of the country's tax system to yield enough tax can be linked to these economic shocks in Kenya's economy.

Policy changes in the 2000s had substantial implications on trade in Kenya. In 2000, African Growth and Opportunities Act (AGOA) was passed by the US government. This agreement aimed at allowing African countries to export garments and textile tax-free. The Kenyan government agreed to the AGOA, thus stimulating the already established Kenya's Export Processing Zone (EPZ). This policy saw the value of textile and garment exports increase from USD 30 million in 2000 to USD 249 million in 2005 (Newman et al., 2016). During the 2000 s, the country experienced increased efficiency in its legal system, good political will and steadiness in implementing tax policy that improved tax revenue (Murunga, Muriithi, \& Kiiru, 2016). However, the gains made in reviving the economy were brought to a halt during 2007/2008 post-election violence that saw the country's economic growth decrease from 6.4 percent in 2007 to 0.23 percent in 2008 (Murunga, 2014).

\subsection{Statement of the Problem}

The Kenyan fiscal deficit has risen from about 2 percent of GDP in 2003 to 8 percent in 2018 (Republic of Kenya, 2004; Republic of Kenya, 2019). This increase can be attributed to the government's desire to respond to its population's needs and accelerate its economic growth and development. For over a decade, the country's tax system has failed to generate adequate revenue compelling the government to turn to both external and internal borrowing in the short run. However, this form of deficit financing is not sustainable both in medium and long term due to their inflationary tendencies in the economy. In addition, these sources of deficit finance cannot be relied upon due to the 2008 world financial meltdown and conditions that the country must meet to get the loans from the donors. To avoid this form of deficit financing, there is a need for a country to design a tax system that can yield enough tax.

In response to this, the government of Kenya has made strides in designing a productive tax system to reduce over-reliance on public debt. Various tax reforms have also been initiated, as enshrined in multiple policy documents but the budget deficit has continued to increase. This means there is need to investigate the 
effectiveness of these reforms. Few studies that delved into this subject include Wawire (2017), Menjo and Kotut (2015), Okech and Mburu (2011), Wawire (2006) and Muriithi and Moyi (2003). The coefficients of these studies may be lower since they did not separate informal sector GDP from the recorded GDP. According to Osoro (1995), the method adopted by these previous studies can only produce valid results if the informal sector is insignificant. Medina et al. (2017) showed that Kenya's informal sector lies between 20 and 40 percent of GDP. Hassan and Schneider (2016) showed that such size of informal sector is significant since it exerts an enormous weight on Kenya's official GDP. It is based on this drawback that this study sought to estimated tax buoyancy and tax elasticity of Kenya's tax system by separating informal sector GDP from recorded GDP. The study adopted the proportional adjustment method using time series data between 1970 and 2018.

\section{Empirical Literature Review}

From 1970 to the early 2000s, a few studies investigated tax productivity associated with tax reforms in Kenya. For instance, Wawire (1991) studied tax performance in Kenya by analyzing tax elasticity, tax ratio and tax effort using the time series data from 1958 to 1989 . This study's finding revealed that though tax revenue increased as the GDP increased, this growth was less than proportionately. These results, therefore, implied that Kenyan tax system during this study's period was inelastic. The study could have revealed more details regarding Kenya's tax performance had it used official GDP instead of recorded GDP. Later, Muriithi and Moyi (2003) studied the tax reforms and their implications on Kenya's tax revenue. The study used data from 1973 to 1999. The study's period was divided into two namely pre-major tax reform (period (1973-1985) and major tax reform period (1986-1999). Tax buoyancy was found to have increased by 62 percent during the major tax reform period, while elasticity was increased by 400 percent. This indicated that reforms had not played a significant role in tax mobilization. During this period, the tax had risen automatically in response to the increase in GDP. This study focused on the then Tax Modernization Programme (TMP). There is need to carry out further investigation given that more tax reforms have been implemented. Some of the later tax reforms can be classified under the Revenue Administration Reforms Modernization Programmes (RARMP) that started in 2004/05.

Other studies that investigated revenue productivity include Kieleko (2006) and Wawire (2006). Kieleko (2006) sought to examine revenue productivity in Kenya for the period between 1973 and 2003. The proportional Adjustment Approach (PAA) was used to estimate the buoyancy and elasticity of Kenya's tax system. Their finding showed that tax reforms during the study period significantly impacted Kenya's tax revenue productivity. The shortcoming of this study is that it only focused on TMP. This study, therefore, improves on this study by investigating not only TMP but also RARMP. Wawire (2006) studied determinants of tax revenue in Kenya using general equilibrium analysis. The study formulated a utility maximization problem and derived a demand function for the public good. In this study, tax revenue was assumed to depend on household income, thus estimating the Engel curve for public goods. The results showed that tax elasticities of total taxes, income taxes and excise duties concerning national income were less than one. Elasticities of excise taxes in terms of imports and trade volume were also found to be less than one. The study found indirect tax to be responsive to changes in GDP. Though this study has adequate observations that permit time series tests, it failed to incorporate other important factors that determine tax revenue, for instance, political and legal environment.

\section{Methodology}

\subsection{Theoretical Framework}

The study adopts Prest (1985) framework in estimating the two indicators of the performance of the tax system, namely tax elasticity and buoyancy. Tax Elasticity is obtained by getting percentage change of tax revenue over the percentage change in a country's GDP. Though tax elasticity is illustrated in aggregated models in the form of a single number, it is, in reality, the weighted mean of sum of elasticities of distinct taxes which often have different responses to changes in GDP. Thus, the response of overall tax to changes in the GDP must be evaluated by studying the elasticities of the individual tax components separately. In turn, the reaction of the separate tax components to changes in GDP can be broken down into two parts: the tax's response to its base and the response of a given tax base to GDP. To show this, let $T_{t}$ represent total tax revenue, $T_{n}$ represents tax revenue from the $\mathrm{n}^{\text {th }}$ tax, $Y$ represents GDP, and $\mathrm{B}_{\mathrm{n}}$ represent the base of the $\mathrm{n}^{\text {th }}$ tax. From this, we can obtain elasticity of overall tax revenue to GDP, elasticity of $n^{\text {th }}$ individual tax component to base and elasticity of $n^{\text {th }}$ individual tax base to GDP in equations 1,2,3 and 4, respectively.

$$
\begin{gathered}
E_{T_{t}, Y}=\frac{\Delta T_{t}}{\Delta Y} * \frac{Y}{T_{t}} . \\
E_{T_{n}, Y}=\frac{\Delta T_{n}}{\Delta Y} * \frac{Y}{T_{n}}
\end{gathered}
$$




$$
\begin{aligned}
E_{T_{n}, B_{n}} & =\frac{\Delta T_{n}}{\Delta B_{n}} * \frac{B_{n}}{T_{n}} \\
E_{B_{n}, Y} & =\frac{\Delta B_{n}}{\Delta Y} * \frac{Y}{B_{n}}
\end{aligned}
$$

Equations 1-4 can be used to break elasticity by types of taxes. For instance, in the case of a tax system of $n$ components of taxes, total tax revenue is expressed as shown in equation 5;

$$
T=T_{1}+\cdots . . T_{m}+\cdots \cdot T_{n}
$$

From equation 5, the elasticity of the total tax revenue can be expressed as a weighted sum of the separate tax elasticities as shown in equation 6;

$$
\mathrm{E}_{\mathrm{T}_{\mathrm{t}}, \mathrm{Y}}=\frac{\mathrm{T}_{1}}{\mathrm{~T}_{\mathrm{t}}}\left[\frac{\Delta \mathrm{T}_{1}}{\Delta \mathrm{Y}} * \frac{\mathrm{Y}}{\mathrm{T}_{1}}\right]+\cdots+\frac{\mathrm{T}_{\mathrm{m}}}{\mathrm{T}_{\mathrm{t}}}\left[\frac{\Delta \mathrm{T}_{\mathrm{m}}}{\Delta \mathrm{Y}} * \frac{\mathrm{Y}}{\mathrm{T}_{\mathrm{m}}}\right]+\frac{\mathrm{T}_{\mathrm{n}}}{\mathrm{T}_{\mathrm{t}}}\left[\frac{\Delta \mathrm{T}_{\mathrm{n}}}{\Delta \mathrm{Y}} * \frac{\mathrm{Y}}{\mathrm{T}_{\mathrm{n}}}\right]
$$

Further, the elasticity of any separate tax to changes in GDP may be broken down into a product of tax elasticity to its base and elasticity of base to GDP. This is illustrated in equation 7.

$$
\mathrm{E}_{\mathrm{T}_{\mathrm{m}}, \mathrm{Y}}=\left(\frac{\Delta \mathrm{T}_{\mathrm{m}}}{\Delta \mathrm{Y}} * \frac{\mathrm{Y}}{\mathrm{T}_{\mathrm{m}}}\right)\left(\frac{\Delta \mathrm{B}_{\mathrm{m}}}{\Delta \mathrm{Y}} * \frac{\mathrm{Y}}{\mathrm{B}_{\mathrm{m}}}\right)
$$

From equation 7 , it can be shown that the elasticity of total tax revenue to GDP in a system of $\mathrm{n}$ taxes is given by:

$$
\left.\left.\left.\mathrm{E}_{\mathrm{T}_{\mathrm{t}}, \mathrm{Y}}=\frac{\mathrm{T}_{1}}{\mathrm{~T}_{\mathrm{t}}}\left[\frac{\Delta \mathrm{T}_{1}}{\Delta \mathrm{Y}} * \frac{\mathrm{Y}}{\mathrm{T}_{1}}\right)\left(\frac{\Delta \mathrm{B}_{1}}{\Delta \mathrm{Y}} * \frac{\mathrm{Y}}{\mathrm{B}_{1}}\right)\right]+\cdots \frac{\mathrm{T}_{\mathrm{m}}}{\mathrm{T}_{\mathrm{t}}}\left[\frac{\Delta \mathrm{T}_{\mathrm{m}}}{\Delta \mathrm{Y}} * \frac{\mathrm{Y}}{\mathrm{T}_{\mathrm{m}}}\right)\left(\frac{\Delta \mathrm{B}_{\mathrm{m}}}{\Delta \mathrm{Y}} * \frac{\mathrm{Y}}{\mathrm{B}_{\mathrm{m}}}\right)\right]+\frac{\mathrm{T}_{\mathrm{n}}}{\mathrm{T}_{\mathrm{t}}}\left[\frac{\Delta \mathrm{T}_{\mathrm{n}}}{\Delta \mathrm{Y}} * \frac{\mathrm{Y}}{\mathrm{T}_{\mathrm{n}}}\right)\left(\frac{\Delta \mathrm{B}_{\mathrm{n}}}{\Delta \mathrm{Y}} * \frac{\mathrm{Y}}{\mathrm{B}_{\mathrm{n}}}\right)\right]
$$

Where $\frac{\Delta B_{m}}{\Delta Y} * \frac{Y}{B_{m}}=1$ for any $\mathrm{m}$ from 1 to $\mathrm{n}$.

\subsection{The Empirical Model}

Tax buoyancy and elasticity were estimated following equation 8. A similar model was adopted by Osoro (1993) and Muriithi and Moyi (2003) to obtain both tax elasticity and tax buoyancy. The latter measures how tax revenue responds to changes in national income and Discretionary Tax Measures (DTMs). Cobb-Douglas (CD) function is used to present the link between tax revenue and national income. The CD function is illustrated in equation 9;

$$
T=e^{\eta} Y^{\beta} e^{\mu}
$$

In equation 9, T represents tax revenue, Y represents the GDP, $\eta$ represents a constant while e is natural number.

For tax buoyancy, equation 9 can be linearized by introducing logarithms on both sides to obtain an estimable model as illustrated in equation 10 ;

$$
\log T=\eta+\beta \log Y+\mu
$$

Equation 10 presents tax buoyancy for total tax revenue. The parameter $\beta$, which is characterized by $0 \leqslant \beta \leqslant 1$, is the buoyancy index.

To obtain the tax elasticity, which shows how the tax revenue responds to the variations in national income only, this study separated Discretionary Tax Measures (DTMs) from the further revenue growth. Prest (1985) showed that to achieve adjusted tax yield by separating amount as a result of discretionary tax measures from the actual tax yield of a given year. This means the left-hand side of equation 10 is adjusted, as shown in equation 11

$$
\log (T-\mathrm{D})=\gamma+\rho \log Y+\varepsilon
$$

Where $(T-D)$ represents the total tax revenue without the Discretionary Tax Measures (DTMs), the total amount of the tax all discretionary tax measure yield. They are obtained from various finance bills. $\gamma$ and $\rho$ are parameters, while $\mu$ is the error term.

Mansfield (1985) showed that to achieve adjusted tax yield by separating amount as a result of DTMs from the actual tax yield of a given year. The adjusted tax yield is again refined by removing continuing effect of each of the discretionary tax measure on future years, as shown in equation 12 .

$$
\mathrm{T}_{\mathrm{ij}}=\mathrm{T}_{\mathrm{j}-1} * \frac{\mathrm{T}_{\mathrm{j}-2, \mathrm{j}-1}}{\mathrm{~T}_{\mathrm{j}-1}} \ldots \ldots \frac{\mathrm{T}_{2,3}}{\mathrm{~T}_{3}} * \frac{\mathrm{R}_{1,2}}{\mathrm{~T}_{2}}
$$

Where;

$T_{j}$ represents the observed tax revenue in a $\mathrm{j}^{\text {th }}$ year.

$T_{i j}$ represents $\mathrm{j}^{\text {th }}$ year's observed tax revenue adjusted to the existing tax structure in year 1.

$T_{j-1, j}=T_{j}-D_{j}$ Where $D_{j}$ is tax revenue effect in the $\mathrm{j}^{\text {th }}$ year of changes in discretionary tax in a given year. 
It can be positive or negative.

Equations 10 and 11 fails to take into consideration unusual circumstances that may affect tax revenue performance. These unique circumstances include institutional changes, for example, independence of the judiciary to curb corruption, weather changes, political instability and demographic factors. Considering that these factors may influence tax revenue, equation 10 and 11 should be re-specified to incorporate these factors. Thus equations 10 and 11 becomes equations 13 and 14, respectively:

$$
\begin{gathered}
T=e^{\eta} \sum_{i=1}^{k} d_{u m_{t}}{ }^{\lambda_{i}} Y^{\beta_{1}} \text { Pop }^{\beta_{2}} e^{\mu} \\
\log (T-\mathrm{D})=e^{\vartheta} \sum_{i=1}^{k} d_{u m_{t}}{ }^{\lambda_{i}} Y^{\omega_{1}} \text { Pop }^{\omega_{2}} e^{\mu}
\end{gathered}
$$

Where dum captures the unusual circumstances. Equation 13 and 14 can be linearized by introducing natural logarithms to become equations 15 and 16 , respectively:

$$
\begin{gathered}
\ln T=\eta+\sum_{i=1}^{2} \lambda_{i} d_{u m_{i}}+\beta_{1} \ln Y+\beta_{2} \ln \text { Popu }+\mu \\
\ln (T-D)=\vartheta+\sum_{i=1}^{2} \lambda_{i} d u m_{i}+\omega_{1} \ln Y+\omega_{2} \ln \text { Popu }+\mu
\end{gathered}
$$

Where $\ln T$ is natural $\log$ of tax revenue, $\ln (T-D)$ is natural $\log$ of adjusted tax revenue, $\ln Y$ is natural $\log$ of official GDP (Obtained by subtracting informal sector GDP from recorded GDP), dum1 is a dummy variable taking a value of 1 for years where there were unusual circumstances that led to adverse effects of tax revenue in Kenya, dum 2 is dummy variable taking a value of 1 for years there were unusual circumstances that led to positive effects on tax revenue in Kenya, logPop illustrates demographic changes. In this equation, $\beta$ is the buoyancy of the tax. If discretionary tax measures are separated, then it becomes the elasticity of the tax.

Choice of official GDP followed Osoro (1995) assertion that in a situation where the informal sector is significantly big, the tax buoyancy and the elasticity estimates based on recorded GDP data might be lower, thus resulting in a false representation of the productivity of a tax system. To calculate size of the informal sector currency demand model was adopted. This model assumes individuals prefer to operate in the informal sector if tax burden is high. In this regard, tax rate is chosen as the major determinant of informal sector where transactions take place in cash form. According to Tanzi (1983), the procedure involves estimating currency outside the bank $C_{1}$ when the tax rate is included in the model. The control variables considered in this model include per capita GDP, deposit rate of interest, inflation and financial innovation. Secondly, an estimate of currency outside the bank $C_{2}$ is again obtained when the model assumes the tax rate is zero. It is expected that currency outside the bank is high when there is a tax rate in the model than when it is assumed to be zero. The difference between $C_{1}$ and $C_{2}$ gives currency circulating in the informal sector $\left(C_{i n f}\right)$, as shown in equation 17.

$$
C_{\text {inf }}=C_{1}-C_{2}
$$

Assuming that velocity of money circulating in informal sector $\left(C_{i n f}\right)$ is similar to that of the formal sector, an estimate of informal sector output (GDPinf) is obtained by getting the product of currency circulating in the informal sector $\left(C_{\text {inf }}\right)$ and velocity of money $(V)$ as shown in equation 18

$$
\text { GDPinf }=V * C_{\text {inf }}
$$

The estimated informal sector's GDP is shown in the Appendix. Official GDP is then obtained by subtracting the informal sector's GDP from the recorded GDP.

\subsection{Variable Description, Their Measurement and Expected Signs}

Variables, their description, measurement and expected signs are discussed in Table 1.

Table 1. Variables, description, measurement and expected signs

\begin{tabular}{llll}
\hline $\begin{array}{l}\text { The Variable and } \\
\text { Abbreviation }\end{array}$ & Definition and Measurement & $\begin{array}{l}\text { Unit } \\
\text { Measurement }\end{array}$ & $\begin{array}{l}\text { Priori Expected Signs and } \\
\text { Source }\end{array}$ \\
\hline Tax Revenue & $\begin{array}{l}\text { The variable measures non-voluntary payment to the } \\
\text { government for which the payer does not obtain direct } \\
\text { benefits. }\end{array}$ & DES \\
& $\begin{array}{l}\text { The variable measures the total value of all the commodities } \\
\text { produced by the formal sector within Kenyan borders in } \\
\text { monetary terms. }\end{array}$ & $\begin{array}{l}\text { Muriithi \& Moyi (2003); } \\
\text { Wawire, (2006) Menjo \& Kotut } \\
\text { (2015) }\end{array}$ \\
\hline
\end{tabular}




\begin{tabular}{|c|c|c|c|}
\hline Dummy variable 1 & $\begin{array}{l}\text { This variable takes the value } 1 \text { for years there were unusual } \\
\text { circumstances that led to adverse effects on Kenya's tax } \\
\text { revenue. These circumstances include Double oil crisis (1976, } \\
\text { 1977), Unfouvarable weather (1983, 1984, 1997, 1998), aid } \\
\text { freeze (1991, 1992, 1993, 1997, 1998) } \\
\text { Import Substitution Strategy (1972), Collapse of EAC } \\
\text { Community (1977), Coffee boom (1976, 1977), SAPs (1986) } \\
\text { Coup Attempt (1982), Influx of refugees (1991, 1992), } \\
\text { Persian Gulf war (1991), ethnic clashes and multiparty } \\
\text { elections (1992, 1997, 2002, 2007, 2012, 2017) }\end{array}$ & Binary & $\begin{array}{l}- \\
\text { Wawire (2006) } \\
\text { Wawire (2017) }\end{array}$ \\
\hline Dummy variable 2 & $\begin{array}{l}\text { This variable takes the value } 1 \text { for years there were unusual } \\
\text { circumstances that led to positive effects on Kenya's tax } \\
\text { revenue. These circumstances include introduction of sales } \\
\text { tax (1973), the VAT introduction (1990), KRA incorporation } \\
\text { (1995), promulgation of the } 2010 \text { constitution making the } \\
\text { judiciary independent (2010). }\end{array}$ & Binary & $\begin{array}{l}+ \\
\text { Wawire (2006) } \\
\text { Wawire (2017) }\end{array}$ \\
\hline Population & $\begin{array}{l}\text { This refers to the number of people between the age of } 15 \text { and } \\
64 \text { during a given year. The variable is used to measure the } \\
\text { number of productive people and thus contribute to tax } \\
\text { revenue. This is the age recognized by ILO. }\end{array}$ & Ratio & $\begin{array}{l}+ \\
\text { Wawire (2006) } \\
\text { Wawire (2017) }\end{array}$ \\
\hline
\end{tabular}

\subsection{Pre-Estimation Tests}

To avoid cases of spurious regression, the study performed unit root tests. Appropriate methods for testing the presence of unit roots in the data series is the Augmented Dickey Fuller (ADF) test, the Phillips-Peron (PP)-test and Zivot-Andrews (Z-A) test. PP test is the most used alternative to ADF since it is non-parametric. It does not require model specification and lagged parameter in the test regression. However, PP may not be the best test because it is based on asymptotic theory. In other words, PP test is designed to test the unit root in the long time series, which is not possible in reality. Zivot and Andrews (1992) and Pesaran (2015) show that both ADF and PP tests are asymptotically equivalent. These authors further asserted that both tests have lower power, and invalid null hypothesis is not rejected in the situation where the coefficient in AR (1) process is close to one. Further, these conventional unit root tests do not account for structural breaks in the data. The unit root that overcomes all these drawbacks is Z-A unit root test. The nature of aggregate time series data requires that unit root tests be conducted before any regression is carried out. If data is non-stationary, this would lead to spurious or inconsistent regression results. The unit roots tests were performed using the ADF test, the PP test and Z-A test, where the null hypothesis is that the series tested contains at least a unit root. Having established the nature of the stationarity of the variables, the study investigated for presence of long run relationship using the Johansen cointegration test (Enders, 2015).

\section{Results}

\subsection{The Descriptive Statistics}

The study established measures of central location and spread of the data shown in models 15 and 16. This was performed to check quality of the data used in the study. The results are shown in Table 2 .

Table 2. Summary statistics

\begin{tabular}{lccccc}
\hline Variables & Observations & Average & Standard Deviation & Minimum value & Maximum value \\
\hline Natural log of Actual Tax & 49 & 10.93 & 2.29 & 5.62 & 1.99 \\
Natural log of Adjusted Tax & 49 & 10.70 & 2.69 & 8.95 & 14.30 \\
Natural log of Official GDP & 49 & 12.43 & 2.00 & 9.24 & 14.29 \\
Natural log of Recorded GDP & 49 & 12.74 & 1.96 & 1.68 & 16.00 \\
Natural log of population & 49 & 2.55 & 0.51 & 0 & 3.34 \\
Dummy Variable 1 & 49 & 0.33 & 0.47 & 0 & 1 \\
Dummy Variable 2 & 49 & 0.22 & 0.42 & & 1 \\
\hline
\end{tabular}

Source: Author's Computations based on data from KNBS.

The summary statistics results revealed that 49 observations were used in this study. Standard deviation results 
showed that for quantitative variables (natural logarithms of actual tax, official tax and population), the natural logarithm of the population of Kenyans between 15 and 64 years had the least standard deviation. This implies that the Kenyan population between 15 and 64 years does not change considerably from one year to another. On testing for multicollinearity, natural logarithm of the population was found to have a Variance Inflating Factor (VIF) of greater than 10. This suggested presence of multicollinearity and a way of ensuring results obtained are precise, the variable was dropped.

\subsection{The Unit Root Results}

The study tested for presence of unit root among the remaining variables using ADF, PP, and Z-A tests. The results are shown in Tables 3 and 4.

Table 3. The Augmented Dickey Fuller and Phillips-Perron Unit Root Tests

\begin{tabular}{|c|c|c|c|c|c|c|c|}
\hline \multicolumn{5}{|l|}{ Augmented Dickey Fuller } & \multicolumn{3}{|c|}{ Phillips-Perron } \\
\hline & & Statistic & $\begin{array}{c}\text { Critical value } \\
(5 \%)\end{array}$ & $\begin{array}{c}\text { Order of } \\
\text { Integration } \\
\end{array}$ & Statistic & $\begin{array}{c}\text { Critical value } \\
(5 \%) \\
\end{array}$ & $\begin{array}{c}\text { Order of } \\
\text { Integration }\end{array}$ \\
\hline $\begin{array}{l}\text { Natural log of actual tax } \\
\text { revenue }\end{array}$ & $\begin{array}{l}\text { Level } \\
1^{\text {st }} \mathrm{D}\end{array}$ & $\begin{array}{c}-1.056 \\
(-10.665)\end{array}$ & $\begin{array}{c}-2.936 \\
(-2.938)\end{array}$ & One & $\begin{array}{c}-0.970 \\
(-13.05)\end{array}$ & $\begin{array}{c}-2.936 \\
(-2.938)\end{array}$ & One \\
\hline $\begin{array}{l}\text { Natural log of adjusted } \\
\text { tax revenue }\end{array}$ & $\begin{array}{l}\text { Level } \\
1^{\text {st }} \mathrm{D}\end{array}$ & $\begin{array}{c}-2.162 \\
(-10.64)\end{array}$ & $\begin{array}{c}-2.936 \\
(-2.938)\end{array}$ & One & $\begin{array}{c}-2.319 \\
(-12.16)\end{array}$ & $\begin{array}{l}-2.936 \\
(-2.938)\end{array}$ & One \\
\hline $\begin{array}{l}\text { Natural } \log \text { of official } \\
\text { GDP }\end{array}$ & $\begin{array}{l}\text { Level } \\
1^{\text {st }} \mathrm{D}\end{array}$ & $\begin{array}{l}-0.581 \\
(-7.399)\end{array}$ & $\begin{array}{c}-2.936 \\
(-2.938)\end{array}$ & One & $\begin{array}{l}-0.594 \\
(-7.414)\end{array}$ & $\begin{array}{l}-2.938 \\
(-2.938)\end{array}$ & One \\
\hline $\begin{array}{l}\text { Natural log of recorded } \\
\text { GDP }\end{array}$ & $\begin{array}{l}\text { Level } \\
1^{\text {st }} \mathrm{D}\end{array}$ & $\begin{array}{c}-0.872 \\
(-8.960)\end{array}$ & $\begin{array}{l}-2.936 \\
(-2.938)\end{array}$ & One & $\begin{array}{l}-1.059 \\
(-8.956)\end{array}$ & $\begin{array}{c}-2.936 \\
(-2.938)\end{array}$ & One \\
\hline
\end{tabular}

Source: Author's Computations based on data from KNBS.

The unit root test results revealed that all the variables used in the study were integrated of order one (stationary at first difference) when both $\mathrm{ADF}$ and PP unit root was used. However, these two-unit root tests fail to give the correct status of the unit root in case there is a structural break. The variables were thus subjected to the Zivot-Andrews unit root test to obtain the correct order of integration, which is a more superior unit root test to both ADF and PP. The results of Z-A unit root test are shown in Table 4.

Table 4. Zivot Andrews Unit Root Test

\begin{tabular}{|c|c|c|c|c|c|c|}
\hline \multicolumn{7}{|l|}{ Trend and intercept } \\
\hline \multirow{2}{*}{ Variables } & \multirow{2}{*}{$\begin{array}{c}\text { Year of } \\
\text { structural break }\end{array}$} & \multicolumn{2}{|c|}{ First difference } & \multicolumn{2}{|c|}{ (Second difference) } & \multirow{2}{*}{$\begin{array}{c}\text { Order of } \\
\text { integration }\end{array}$} \\
\hline & & t-statistics & $5 \%$ critical value & t-statistics & $5 \%$ critical value & \\
\hline Natural log of Tax Revenue & 2010 & 4.828 & -4.80 & -15.215 & -4.80 & one \\
\hline Natural log of adjusted tax revenue & 2010 & -2.606 & -4.80 & -7.421 & -4.80 & one \\
\hline Natural $\log$ of official GDP & 2011 & 1.302 & -4.80 & -7.713 & -4.80 & one \\
\hline Natural log of recorded GDP & 2002 & -4.766 & -4.80 & -10.327 & -4.80 & one \\
\hline
\end{tabular}

Source: Author's Computations based on data from KNBS.

Results in Table 4 illustrate that the Z-A test results agree with both ADF and PP tests by presenting variables integrated of order one. The structural breaks among the variables as established by the Z-A test coincide with the identifiable political shock that occurred in 2002 and the promulgation of the 2010 constitution that resulted in an independent judiciary. Structural breaks that can be attributed to the court's independence thus giving KRA impetus to prosecute tax evaders are observed in 2010 and 2011. Having found out that all variables were nonstationary, the study suspected the presence of a long-run relationship. The study adopted the Johansen's test of cointegration in examining long-run association among variables. However, lag length was established first in both Johansen cointegration test and the preceding vector autoregressive. The results on lag length selection are discussed in section 4.3.

\subsection{Lag Length Selection}

The study used the five lag length selection criteria to establish a suitable lag length for the study. The criteria considered were Final Prediction Error (FPE), the Likelihood Ratio (LR), the Akaike Information Criteria (AIC), the Hannan and Quinn information criterion (HQIC) and Schwarz's Bayesian information criterion (SBIC). 
HQIC and SBIC suggested one lag for buoyancy, while the other three namely LR, FPE and AIC suggested three lags. The study, therefore, chose one lag as suggested by SBIC, given that it is a stricter test. For elasticity, the lag length results show that LR, AIC and FPE suggest three lags lag while HQIC and SBIC suggest one lag. The study, therefore, chose one lag as suggested by SBIC, given its stated characteristics.

\subsection{Johansen Cointegration Test}

Having established the estimated model's lag length, existence of a long-run relationship was investigated. Tables 5 and 6 shows the results. Table 5 illustrates cointegration results for estimating buoyancy. Cointegration results for elasticity model are indicated in Table 6.

Table 5. Johansen tests for Cointegration for Bouyancy Model

\begin{tabular}{lllllr}
\hline $\begin{array}{l}\text { Trend: Constant } \\
\text { Sample: } 1970-2018\end{array}$ & Lags $=1$ & & & \\
\hline Maximum rank & parms & LL & Eigen value & Trace statistic & Value \\
\hline 0 & 3 & -4.49 & - & 34.85 & 29.68 \\
1 & 8 & 8.25 & 0.411 & $9.379^{*}$ & 15.41 \\
2 & 11 & 12.72 & 0.170 & 0.424 & 3.76 \\
3 & 12 & 12.94 & 0.00879 & & \\
\hline
\end{tabular}

Source: Author's Computations based on data from KNBS.

From Table 5, the long-run relationship between tax revenue and the explanatory variable was established due to the cointegrating vector being revealed. At maximum rank 0 , the null hypothesis $\left(\mathrm{H}_{0}\right)$ implies absence of cointegration and alternative hypothesis $\left(\mathrm{H}_{\mathrm{a}}\right)$ implies presence of cointegration. Since the trace statistic at rank 0 (34.85) is greater than the critical value (29.68) testing at a 5 percent level of significance, it implies that the null hypothesis is rejected, thus shifting investigation to maximum rank 1 . At this rank, one cointegrating equation is tested at $\mathrm{H}_{0}$, whereas $\mathrm{H}_{\mathrm{a}}$ tests the presence of many cointegrating equations. Trace statistic at this given point (9.38) is less than the critical value (15.41), testing at 95 percent confidence interval revealed presence of one cointegrating equation.

Table 6. Johansen tests for Cointegration for Elasticity Model

\begin{tabular}{lllllr}
\hline $\begin{array}{l}\text { Trend: Constant } \\
\text { Sample: } 1970-2018\end{array}$ & Lags $=1$ & & & \\
\hline Maximum rank & parms & LL & Eigen value & Trace statistic & Value \\
\hline 0 & 3 & -41.63 & - & 34.89 & 29.68 \\
1 & 8 & -28.63 & 0.418 & $9.878^{*}$ & 15.41 \\
2 & 11 & -23.85 & 0.180 & 0.328 & 3.76 \\
3 & 12 & -23.69 & 0.00681 & & \\
\hline
\end{tabular}

Source: Author's Computations based on data from KNBS.

From Table 6, it is evident that there is one cointegrating equation because the $\mathrm{H}_{0}$ of no cointegrating equation at rank 1 was rejected. Having established presence of cointegration, the study proceeded to estimate VECM. The results are discussed in the following section.

\subsection{VECM Regression Results}

VECM framework was implemented, and the results are illustrated in Table 7. The estimated equations were 15 and 16 for tax buoyancy and elasticity, respectively. From the results dummy variable that takes 1 for years, some circumstances led to adverse effects on tax revenue (Dummy variable 1) was dropped from VECM model due to problem of dummy variable trap. However, the constant captured its impact on tax revenue in the buoyancy model and adjusted tax revenue in elasticity model. In addition, population variable was dropped due to the problem of multicollinearity. 
Table 7. VECM results

\begin{tabular}{|c|c|c|c|c|}
\hline & \multicolumn{2}{|c|}{ Buoyancy } & \multicolumn{2}{|c|}{ Elasticity } \\
\hline & \multicolumn{2}{|c|}{ Dependent variable } & \multicolumn{2}{|c|}{ Dependent variable } \\
\hline & \multicolumn{2}{|c|}{ Natural log of actual tax } & \multicolumn{2}{|c|}{ Natural log of adjusted tax } \\
\hline \multirow[t]{2}{*}{ ECT } & $-0.4 * * *$ & $-0.8 * * *$ & $-0.2 * * *$ & $-0.3 * * *$ \\
\hline & $(0.08)$ & $(0.11)$ & $(0.06)$ & $(0.07)$ \\
\hline \multirow[t]{2}{*}{ Natural log of Official GDP } & $1.28 * * *$ & & $0.91 * * *$ & \\
\hline & $(0.07)$ & & $(0.13)$ & \\
\hline \multirow[t]{2}{*}{ Natural log of recorded GDP } & & $1.24 * * *$ & & $0.89 * * *$ \\
\hline & & $(0.04)$ & & $(0.098)$ \\
\hline \multirow[t]{2}{*}{ Dummy Variable 2} & $1.51^{* * *} *$ & $0.83 * * *$ & $2.83 * * *$ & $2.31 * * *$ \\
\hline & $(0.34)$ & $(0.16)$ & $(0.60)$ & $(0.44)$ \\
\hline \multirow[t]{2}{*}{ Constant } & 0.034 & 4.53 & 0.033 & 0.73 \\
\hline & $(0.064)$ & $(-)$ & $(0.67)$ & $(-)$ \\
\hline Observation & 49 & 48 & 49 & 48 \\
\hline $\mathrm{F}(\mathrm{p}>\mathrm{ch} 2$ & $0.00 * * *$ & $0.00 * * *$ & $0.00 * * *$ & $0.00 * * *$ \\
\hline Lagrange Multiplier Test & 0.98 & 0.95 & 0.24 & 0.97 \\
\hline Jarque-Bera Test & $0.00 * * *$ & $0.00 * * *$ & $0.00 * * *$ & $0.00 * * *$ \\
\hline
\end{tabular}

Note. Standard errors in parentheses.

$* * * \mathrm{p}<0.01, * * \mathrm{p}<0.05, * \mathrm{p}<0.1$.

From Table 7, it is evident that all regressions of tax buoyancy and elasticity performed well with regards to overall model fit. This is illustrated by the significant p-value (0.00) of the F test. This suggests that all variables considered in this model are jointly important determinants of Kenya's tax revenue and adjusted tax revenue at a 99 percent confidence level for the buoyancy and elasticity model, respectively.

The study went a step further to determine the presence of autocorrelation and stability of both buoyancy and elasticity models. Autocorrelation and stability tests revealed that the optimal lag length for both models was one. At this lag, the LM statistics showed that the disturbance terms were not statistically different from zero. Therefore, the models with lag one did not have autocorrelation problems. Results for stability showed that the VECM models were stable, implying results obtained for both buoyancy and elasticity were valid as the roots lay within the unit circle for each model (See Figures A.1 and A.2 in the Appendix). Thus, lag one was the optimal lag length for both models. This was important for the VECM models as instability may suggest model misspecification and, therefore, inability to use the models for forecasting.

In estimating tax buoyancy and elasticity, the coefficients of the ECT are negative and significant at a 1 percent level. This fulfils the requirement for the existence of a long-run relationship among variables. The coefficients of ECT implies that if there were disequilibrium between tax revenue and explanatory variables, it would take about 5 months ( 0.4 of 12 months) and 2 months ( 0.2 of 12 months) for the equilibrium to be restored for the buoyancy and elasticity model respectively. This applies to the buoyancy and elasticity models with official GDP as the independent variable. For buoyancy and elasticity models, results revealed that it would take about 9.6 months ( 0.8 of 12 months) and 3.6 months ( 0.3 of 12 months) for the equilibrium to be restored if there was a disequilibrium. The results further revealed a coefficient of tax buoyancy that was greater than that of tax elasticity. This showed that the tax reforms that government of Kenya implemented from 1970 to 2018 contributed to the improved performance of the country's tax revenue.

The results revealed a significant buoyancy coefficient of 1.28. This showed that Kenya's tax system is buoyant, given that the coefficient was more significant than one. The coefficient implies that if the natural log of official GDP and discretionary tax measures aimed at making tax revenue respond to GDP increases by one percent, tax revenue collection increases by 1.28 percent. The study also estimated tax buoyancy using recorded GDP and the results are in agreement with Osoro (1995) since buoyancy coefficient was lower. These results align with several previous studies that established the effectiveness of discretionary tax measures in improving revenue collection. These previous studies include Ole (1975), Njoroge (1997), Muriithi and Moyi (2003), Kieleko (2006), Wawire (2006), Gituku (2011) and Omondi et al. (2014). However, these studies may have underestimated the buoyancy coefficient due to their failure to separate informal sector's GDP.

In estimating tax elasticity, results showed a significant elasticity coefficient of 0.91 . This indicates that Kenya's 
tax system is inelastic, meaning that tax revenue is not very sensitive to increased Kenya's official GDP. This means that unless reforms are embraced fully, tax revenue may not respond proportionately or more proportionately to the rise in GDP. Specifically, the findings showed that if the natural log of official GDP increases by one percent, the natural $\log$ of adjusted tax revenue increases by 0.91 percent. The failure of Kenya's tax system to respond to a rise in GDP can be linked to poor tax administration that makes taxpayers under-report their incomes. In addition, many businesses, especially within the agricultural sector, benefit from tax exemptions, thus denying the tax authority some tax revenue. On using recorded GDP, the study obtained coefficient of elasticity that was lower than that of official GDP. This finding is in agreement with Osoro (1995) with regards to failure to separate informal sector's GDP. The study's findings conform to Ole (1975), Njoroge (1997), Wawire (2006), Gituku (2011) and Omondi et al. (2014) findings.

The coefficients for dummy variables included in the buoyancy and elasticity model for the unusual circumstances that contributed positively to tax revenues were significant. These unusual circumstances include the introduction of sales tax (1973), VAT introduction (1990), KRA incorporation (1995), promulgation of 2010 constitution making the judiciary independent (2010). These results are in line with Wawire (2006).

\section{Policy Implication}

The empirical results in this study present direct implications for tax reform in Kenya. Though these results paint an encouraging tax reform experience, more can be done to improve tax collection. For instance, there is a need to review and rationalize tax rates to improve the taxation process. An elastic tax system is suitable for developing countries because it implies that tax mobilization will grow naturally with growing GDP without increasing tax rates, a politically sensitive action (Due, 1981). The failure of the tax system to respond to country GDP may be a result of poor tax administration coupled with the existence of generous exemptions. This, therefore, means that KRA needs to direct tax reform at improving tax administration. The reforms should also target reducing or eliminating the tax exemptions, which erode the effective tax base.

\section{Funding}

This work was funded by African Economic Research Consortium (AERC) (2019).

\section{References}

Atambo, P., \& Katuse, P. (2017). Challenges in the Implementation of the Business Automation Project at Kenya Revenue Authority (KRA): A Case of Kenya Revenue Authority. European Journal of Business and Strategic Management, 2(3), 89-116.

Bigsten, A., Kimuyu, P., \& Söderbom, M. (2010). The Manufacturing Sector: Policies for Prosperity. Nairobi: Oxford University Press. https://doi.org/10.1093/acprof:oso/9780198776987.001.0001

Eissa, N. O., \& Jack, W. (2010). Tax reform in Kenya: Policy and administrative issues. Taxation in Developing Countries: Six Case Studies and Policy Implications, 198. https://doi.org/10.7312/gord14862-009

Enders, W. (2015). Applied Econometric Time Series. New Jersey: John Wiley \& Sons.

Hassan, M., \& Schneider, F. (2016). Modelling the Egyptian shadow economy: A currency demand and a MIMIC model approach. Journal of Economics and Political Economy, 3(2), 309-339.

Karingi, S. N., \& Wanjala, B. (2005). The tax reform experience of Kenya. WIDER Research Paper. Helsinki: United Nations University.

Kieleko, P. M. (2006). The effects of tax reforms on tax productivity in Kenya. Unpublished M. A Project. University of Nairobi, Kenya.

Kinyanjui, B. K. (2013). Reversed Fortunes in the South: A Comparison of the Role of FDI in Industrial Development in Kenya and Malaysia. Leiden: University of Leiden, African Studies Centre.

Kondo, E. M. (2015). The effect of revenue enhancement strategies on financial performance of Kenya revenue authority. Unpublished MA project, University of Nairobi, Kenya.

Menjo, I. K., \& Kotut, S. C. (2015). Decomposition of the Tax-to-Income Elasticity of Major Taxes in Kenya. $\begin{array}{llll}\text { Research Journal of } \text { Finance and } & \text { Accounting, }\end{array}$ https://citeseerx.ist.psu.edu/viewdoc/download?doi=10.1.1.993.7128\&rep=rep1\&type=pdf

Moyi, E., \& Ronge, E. (2006). Taxation and tax modernization in Kenya: A diagnosis of performance and options for further reform. Nairobi: Institute of Economic Affairs.

Muhammad, S. D., \& Ahmed, Q. M. (2010). Determinant of Tax Buoyancy: Empirical Evidence from 
Developing Countries. European Journal of Social Sciences, 13(3), 408-414.

Muriithi, M. K., \& Moyi, E. D. (2003). Tax Reforms and Revenue Mobilization in Kenya. Research Paper No. 131, African Economic Research Consortium (AERC), Nairobi.

Murunga, J. (2014). An Empirical Investigation of Factors Influencing Tax Effort in Kenya. Unpublished master degree thesis, University of Nairobi, Kenya.

Murunga, J. (2016). Tax effort and determinants of tax ratios in Kenya. European Journal of Economics, Law and Politics, 3(2), 24-36. https://doi.org/10.19044/elp.v3no2a2

Mutua, J. N. (2012). A Citizen's Handbook on Taxation in Kenya. Nairobi: Institute of Economic Affairs.

Newman, C., Page, J., Rand, J., Shimeles, A., Söderbom, M., \& Tarp, F. (Eds.). (2016). Manufacturing transformation: Comparative studies of industrial development in Africa and emerging Asia. Helsinki: United Nations University. https://doi.org/10.1093/acprof:oso/9780198776987.001.0001

Okech, T. C., \& Mburu, P. G. (2011). Analysis of responsiveness of tax revenue to changes in national income in Kenya between 1986 and 2009. International Journal of Business and Social Science, 2(21), 275-287.

Omondi, V. O., Wawire, N. H., Manyasa, E. O., \& Thuku, K. G. (2014). Effects of Tax Reforms on Buoyancy and Elasticity of the Tax System in Kenya. International Journal of Economics and Finance, 6(10), 97-111. https://doi.org/10.5539/ijef.v6n10p97

Osoro, N. E. (1993). Revenue productivity implications of tax reform in Tanzania. Research Paper No. 20, African Economic Research Consortium (AERC), Nairobi.

Osoro, N. E. (1995). Tax reforms in Tanzania: Motivations, directions and implications. Research Paper No. 38, African Economic Research Consortium (AERC), Nairobi.

Osoro, N. E. (1990). The Revenue Generating Potentials of the Tanzania Tax System. Tanzania Journal of Economics, 1(1), 53-62.

Pesaran, M. H. (2015). Time series and panel data econometrics. Oxford University Press. https://doi.org/10.1093/acprof:oso/9780198736912.001.0001

Prest, A. R., \& Barr, N. (1985). Public finance in theory and practice. London: Weidenfeld \& Nicolson.

Republic of Kenya. (1997). Economic Survey. Nairobi: Government printer.

Republic of Kenya. (2004). Economic Survey. Nairobi: Government printer.

Republic of Kenya. (2017). Economic Survey. Nairobi: Government printer.

Republic of Kenya. (2019). Economic Survey. Nairobi: Government printer.

Wawire, N. (2017). Determinants of value added tax revenue in Kenya. Journal of Economics Library, 4(3), 322-344.

Wawire, N. H. W. (1991). An empirical assessment of tax performance in Kenya. Unpublished MA project, Kenyatta University, Kenya.

Wawire, N. H. W. (2006). The determinants of tax revenue in Kenya. Unpublished PhD thesis, Kenyatta University, Kenya.

Zivot, E., \& Andrews, W. K. (1992). Further Evidence on the Great Crash, the Oil Price Shock and the Unit Root Hypothesis. Journal of Business and Economics Statistics, 10, 251-270. https://doi.org/10.1080/07350015.1992.10509904 


\section{Appendix}

Table A3. The Size of the Informal Sector in KES B, 1970-2018

\begin{tabular}{cccc}
\hline Year & Size of the Informal Sector (KES B) & Year & Size of the Informal Sector (KES B) \\
\hline 1970 & 2.62 & 1995 & 225.29 \\
1971 & 2.23 & 1996 & 255.35 \\
1972 & 3.20 & 1997 & 296.08 \\
1973 & 3.48 & 1998 & 334.96 \\
1974 & 4.14 & 1999 & 163.66 \\
1975 & 3.48 & 2000 & 129.96 \\
1976 & 3.91 & 2001 & 159.70 \\
1977 & 7.09 & 2002 & 144.66 \\
1978 & 6.39 & 2003 & 185.20 \\
1979 & 8.57 & 2004 & 245.18 \\
1980 & 13.87 & 2005 & 199.30 \\
1981 & 20.23 & 2006 & 272.11 \\
1982 & 26.76 & 2007 & 287.56 \\
1983 & 32.13 & 2008 & 319.96 \\
1984 & 25.00 & 2009 & 369.58 \\
1985 & 22.80 & 2010 & 369.70 \\
1986 & 29.27 & 2011 & 489.35 \\
1987 & 23.10 & 2012 & 619.88 \\
1988 & 44.66 & 2013 & 594.91 \\
1989 & 85.35 & 2014 & 551.52 \\
1990 & 79.57 & 2015 & 782.31 \\
1991 & 102.52 & 2016 & 1080.40 \\
1992 & 94.89 & 2017 & 1427.90 \\
1993 & 102.51 & 2018 & 2067.99 \\
1994 & 193.24 & & \\
\hline
\end{tabular}

Source: Author's Computations based on data from KNBS.

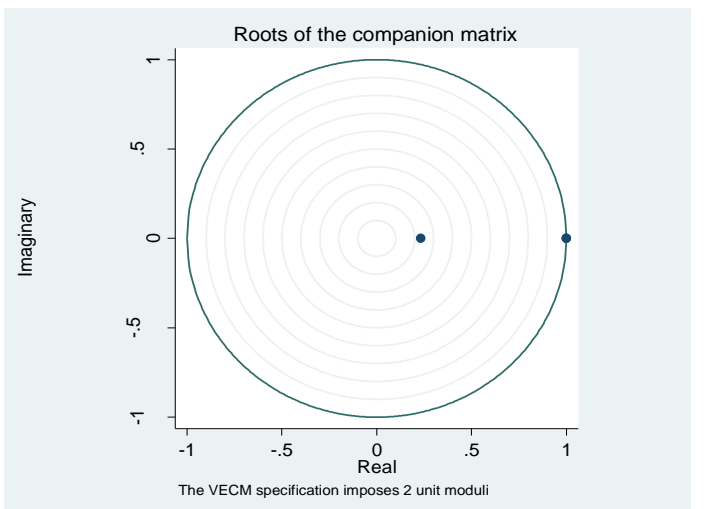

Figure A1. Model stability for the Buoyancy Model

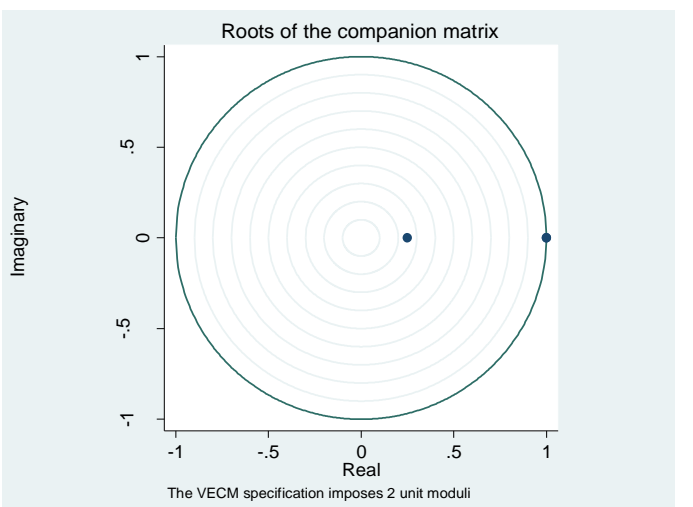

Figure A2. Model stability for the Elasticity Model

\section{Copyrights}

Copyright for this article is retained by the author(s), with first publication rights granted to the journal.

This is an open-access article distributed under the terms and conditions of the Creative Commons Attribution license (http://creativecommons.org/licenses/by/4.0/). 